\title{
Alpha-Lipoic Acid Downregulates IL-1 $\beta$ and IL-6 by DNA Hypermethylation in SK-N-BE Neuroblastoma Cells
}

\author{
Simona Dinicola ${ }^{1}$, Sara Proietti ${ }^{2}$, Alessandra Cucina ${ }^{2}$, Mariano Bizzarri ${ }^{1}$ and Andrea Fuso ${ }^{2, *}$ \\ 1 Department of Experimental Medicine, Sapienza University of Rome, Viale Regina Elena 324, \\ 00161 Rome, Italy; simona.dinicola@uniroma1.it (S.D.); mariano.bizzarri@uniroma1.it (M.B.) \\ 2 Department of Surgery "Pietro Valdoni", Sapienza University of Rome, Via Antonio Scarpa 16, \\ 00161 Rome, Italy; sara.proietti@uniroma1.it (S.P.); alessandra.cucina@uniroma1.it (A.C.) \\ * Correspondence: andrea.fuso@uniroma1.it; Tel.: +39-064-976-6604
}

Received: 26 July 2017; Accepted: 23 September 2017; Published: 26 September 2017

\begin{abstract}
Alpha-lipoic acid (ALA) is a pleiotropic molecule with antioxidant and anti-inflammatory properties, of which the effects are exerted through the modulation of NF-kB. This nuclear factor, in fact, modulates different inflammatory cytokines, including IL-1b and IL-6, in different tissues and cell types. We recently showed that IL-1b and IL-6 DNA methylation is modulated in the brain of Alzheimer's disease patients, and that IL-1b expression is associated to DNA methylation in the brain of patients with tuberous sclerosis complex. These results prompted us to ask whether ALA-induced repression of IL- $1 \mathrm{~b}$ and IL-6 was dependent on DNA methylation. Therefore, we profiled DNA methylation in the 5'-flanking region of the two aforementioned genes in SK-N-BE human neuroblastoma cells cultured in presence of ALA $0.5 \mathrm{mM}$. Our experimental data pointed out that the two promoters are hypermethylated in cells supplemented with ALA, both at $\mathrm{CpG}$ and non-CpG sites. Moreover, the observed hypermethylation is associated with decreased mRNA expression and decreased cytokine release. These results reinforce previous findings indicating that IL-1b and IL-6 undergo DNA methylation-dependent modulation in neural models and pave the road to study the epigenetic mechanisms triggered by ALA.
\end{abstract}

Keywords: DNA methylation; IL-1b; IL-6; epigenetics; inflammation; lipoic acid; neuroblastoma

\section{Introduction}

The role of alpha-lipoic acid (ALA), also known as thioctic acid, as an antioxidant and anti-inflammatory molecule is largely known [1]. In particular, it is an object of great interest for its high antioxidant capacity and peculiar ability to challenge the production of free radicals in both lipophilic and hydrophilic environments, and ability to maintain its antioxidant properties both in its oxidised and reduced form [2-4].

Antioxidant action of ALA is mediated by two essential nuclear factors: nuclear factor erythroid 2-related factor 2 (Nrf2) and nuclear factor kappa-light chain-enhancer of activated B cells (NF-kB) [5-10]. Amongst the many cytokines under transcriptional control of these NFs, IL-1 $\beta$ and IL-6 represent two relevant pro-inflammatory cytokines involved in pathological processes in many different tissues and cell types [11-15]. These two genes are of particular interest regarding our scopes, since it is already known that they are regulated by ALA and are involved in neurodegenerative processes [16]. Therefore, ALA has been proposed as useful in adjuvant treatment for the management of different human diseases [17], including diabetes, cardiovascular disease, bone loss, inflammatory chronic disease, and others, including neurodegenerative diseases and 
neuropathy $[18,19]$. Overall, the preliminary data provided the rationale for ALA-based anti-aging treatment $[9,20]$.

The preading of neurodegenerative diseases associated with aging, particularly Alzheimer's disease (AD), has become a public health priority and challenge. AD affects approximately 44 million people worldwide, with the rate estimated to increase, which could result in 115 million people being affected by 2050 [21]. AD is characterised by progressive cognitive decline, along with the presence of intracellular deposits of fibrillary hyper-fosforylated Tau and extracellular deposits of aggregated amyloid- $\beta(A \beta)$ protein [22] in the brains of infected subjects. No effective therapies are known as of yet. Due to the lack of early diagnostic biomarkers and predictive specific symptoms, AD can remain asymptomatic for a long time before cognitive decline is evident. Therefore, early intervention and preventive strategies could help to counteract the molecular processes at the origin of this pathology [23]. Many different molecular pathways are dysregulated in AD, and could be potentially relevant in planning intervention aimed at preventing and/or curing the disease. Oxidative stress represents one of the major pathogenic mechanisms associated with AD pathological processes; although it is not yet completely clear how much oxidation can be causative or consequential of the disease $[24,25]$. From a causative perspective, it is known that oxidative stress is responsible for increased $A \beta$ production and accumulation. However, $A \beta$ can, in turn, increase oxidative stress per se $[26,27]$. Therefore, several antioxidant molecules are currently under scrutiny for their possible beneficial effects in the treatment of $\mathrm{AD}$ and neurodegenerative diseases.

Oxidative stress is generally associated with inflammation in AD and neurodegeneration, since both pro- and anti-inflammatory cytokines are modulated by oxidative stress and antioxidant response [28]. It is noteworthy that IL-1 $\beta$ and IL-6 are amongst the cytokines modulated by the ALA and are also involved in the inflammatory processes associated with $\mathrm{AD}$ and neurodegeneration [29-31]. In particular, IL-1 $\beta$ and IL-6 showed characteristic expression patterns at mRNA and protein levels in the brain of AD patients at different stages of the pathology [27]. It was possible to demonstrate that the specific patterns of mRNA expression correlated with the DNA methylation patterns in the promoters of the two genes [32]. This finding is indeed in agreement with the already known observation that IL- $1 \beta$ and IL- 6 expression can be regulated by DNA methylation or other epigenetic mechanisms in different tissues and conditions [33-37].

Recently, we demonstrated that ALA-dependent regulation of IL- $1 \beta$ and IL- 6 expression is associated to the modification of the DNA methylation of the respective promoters; specifically, we observed that ovarian epithelial cells treated with ALA undergo hypermethylation of IL-1 $\beta$ and IL-6 5'-flanking regions and consequent down-regulation at mRNA and protein levels [38]. On this basis, we aimed at demonstrating that the same epigenetic mechanism was associated with ALA-dependent down-regulation of IL-1 $\beta$ and IL-6 in neuronal cells. Therefore, we treated SK-N-BE human neuroblastoma cells, previously used as a model to study AD-associated mechanisms with ALA [39-41]. We investigated the DNA methylation profile by bisulphite transformation, and the expression of IL- $1 \beta$ and IL- 6 at mRNA and protein levels by real-time polymerase chain reaction (RT-PCR) and Enzyme-Linked Immunosorbetn Assay (ELISA), respectively.

\section{Materials and Methods}

\subsection{Cell Cultures}

According to the experimental plan, human neuroblastoma SK-N-BE cells (acquired from the American Type Culture Collection, Manassas, VA, USA) were plated in 10\% Foetal Calf Serum (FCS)-containing medium, and after $24 \mathrm{~h}$ of growth, the cells were shifted to control medium $(10 \% \mathrm{FCS}$, $1 / 1000$ dimethylsulphoxyde, DMSO) or ALA $0.5 \mathrm{mM}$ (dissolved in DMSO) supplemented medium. After $24 \mathrm{~h}$ of culture, cells were collected and stored at $-80^{\circ} \mathrm{C}$ for the following DNA or RNA purification. At $24 \mathrm{~h}$, supernatants were also collected and stored at $-80^{\circ} \mathrm{C}$ for the following ELISA test. For each assay, three samples per condition were assessed, and each experiment was independently 
repeated three times. ALA was supplied by Lo.Li.Pharma (Rome, Italy) in a racemic mixture $(R / S, 1: 1)$ and dissolved in DMSO at a concentration of $500 \mathrm{mM}$ (ALA solubility in DMSO: 1.5 M).

\subsection{DNA Methylation Study by Bisulphite Modification and Genomic Sequencing}

DNA isolation from cells was performed using the DNeasy Blood and Tissue Kit (Cat. \#69504, Lot \#136269927, Qiagen, Milan, Italy) and the Qiacube instrument (Qiagen, Milan, Italy).

Bisulphite analysis of IL-1B and IL-6 promoter methylation was performed as previously described [26,37] using the EpiTect Bisulphite kit; PCR products obtained after bisulphite conversion were cloned using the PCR Plus Cloning Kit (both from Qiagen, Milan, Italy). At least ten positive bacterial clones per experimental condition were sequenced using M13 primers (in service by PRIMM, Milan, Italy).

The methylation patterns were assessed by recognition of the modified cytosine residues by comparing the sequencing outputs with Genbank DNA sequences; for each clone, methylation was reported as 1/0 value in an Excel spreadsheet (methylated: 1; unmethylated: 0). Methylation percentage was calculated for each sample at single cytosine level by the formula: $\left(\mathrm{n}^{\circ}\right.$ methylC $/ \mathrm{n}^{\circ}$ sequenced clones $) \times 100$. Finally, we calculated the average methylation percentage over the experimental repetition for each experimental group.

Methylation insensitive primers (MIPs) used for bisulphite analysis were already described [26,37]; these primers were designed to assess the methylation status of the plus $\left(5^{\prime} \rightarrow 3^{\prime}\right)$ DNA strand. Positive and negative controls necessary to guarantee complete and efficient bisulphite conversion were prepared as previously described [26,37], and were treated and analysed in parallel with the experimental samples.

\section{3. mRNA Expression Study by Real-Time PCR}

RNA isolation from cells was performed using the RNeasy mini kit (Qiagen, Milano, Italy) and cDNA synthesised as previously described; $1 \mu \mathrm{g}$ of total cDNA was used for real-time reactions; analyses were performed in triplicate for each sample as previously described [37]. cDNA levels were normalised to the $\beta$-actin control, and presented as the fold increase (ratio of the experimental gene value/ $\beta$-actin gene value) over the control sample. GAPDH and $18 \mathrm{~S}$ were also used to normalise the PCR reactions with comparable results (Supplementary Figure S1).

\subsection{Cytokines Production Study by ELISA Test}

Levels of cytokines released in the culture medium were determined by ELISA following the manufacturer's instructions, using the following kits: IL-1 $\beta$ beta, sensitivity: $6.5 \mathrm{pg} / \mathrm{mL}$ (Abcam, ab46052); IL-6, sensitivity: 0.7 pg/mL (Quantikine, R\&D, D6050). ELISA plates were analysed by a microtiter plate reader (Opsys MR; Dinex Technologies, Chantilly, VA, USA).

\subsection{Statistical Analysis}

Statview 5.0 (SAS Institute, Milan, Italy) statistical software was used to apply the statistical analysis as previously described $[31,38]$. Briefly, methylation data were analysed by Mann-Whitney non-parametric tests; One-way Analysis of Variance (ANOVA) and Tuckey's post-test were applied to calculate significant differences in real-time PCR and in ELISA assays; Pearson's correlation was computed to assess the correlation between DNA methylation and mRNA expression.

\section{Results}

DNA methylation status of CpG and non-CpG moieties in the $5^{\prime}$-flanking regions of the $I L-1 \beta$ and $I L-6$ genes has been studied by bisulphite treatment of genomic DNA purified from human neuroblastoma SK-N-BE cells, cultured for $24 \mathrm{~h}$ in control or $0.5 \mathrm{mM}$ ALA supplemented medium. Methylation profiles at single cytosine level are reported in Figure 1. Although both gene promoters 
show significant hypomethylation associated to ALA treatment, the difference in IL-1 $\beta$ (Figure 1A) methylation profile in ALA vs. control is more marked than in IL-6 (Figure 1B) promoter. In fact, Mann-Whitney test reports higher statistical significance $(U=9.00, p<0.001)$ for IL-1 $\beta$ than for IL-6 $(\mathrm{U}=9.00, p<0.05)$. As in previous experiments from our laboratory [26,37], differences in methylation levels were observed even at nonCpG sites, that actually also show the greater differences with respect to the CpG moieties.
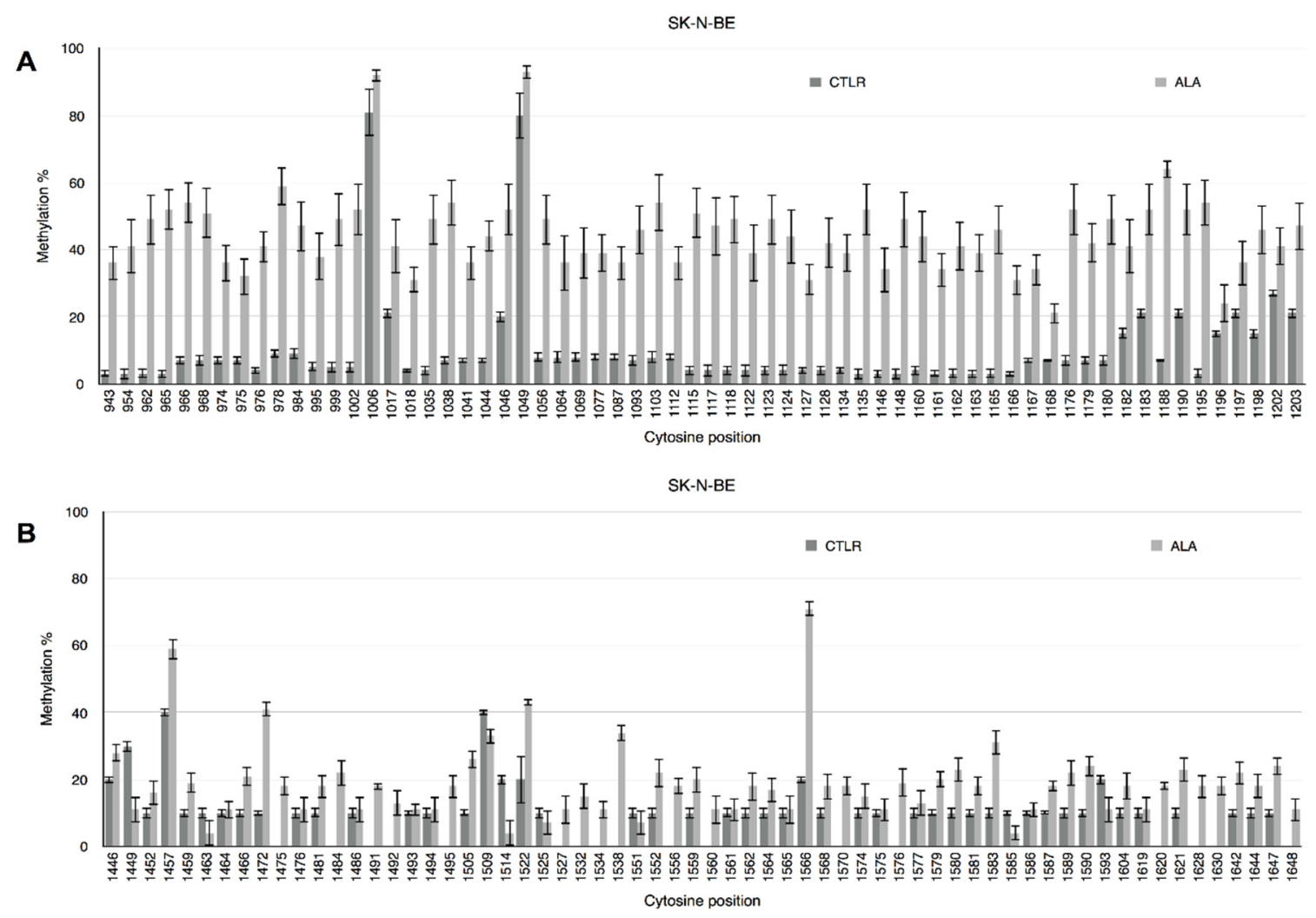

Figure 1. Methylation pattern of $I L-1 \beta$ and $I L-65^{\prime}$-flanking regions. $C p G$ and non-CpG site-specific methylation pattern expressed as percent methylation for each cytosine in the investigated region of the human $I L-1 \beta$ (A) and $I L-6$ (B) promoters. Cytosine position in the reference sequence is indicated below the $x$-axis. Dark grey columns represent control cells, light grey columns represent alpha-lipoic acid (ALA)-treated cells.

As shown in Figure 2, IL-1 $\beta$ (Figure 2A) and IL-6 (Figure 2B) gene expression is significantly down-regulated in ALA-treated cells and is therefore inversely correlated to DNA methylation (IL-1 $\beta$ : $r=0.96 ;$ IL-6: $r=0.81, p<0.01$ ).

The levels of the two cytokines secreted in the culture medium was assessed by ELISA tests and is concordant with mRNA levels; indeed, IL-1 $\beta$ (Figure 2C) and IL-6 (Figure 2D) are more abundant in control medium and lower in the medium of cells treated with $0.5 \mathrm{mM}$ ALA. 
A

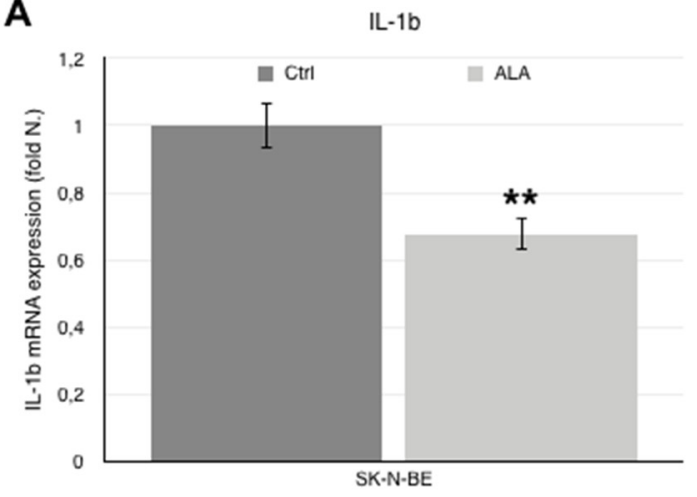

C

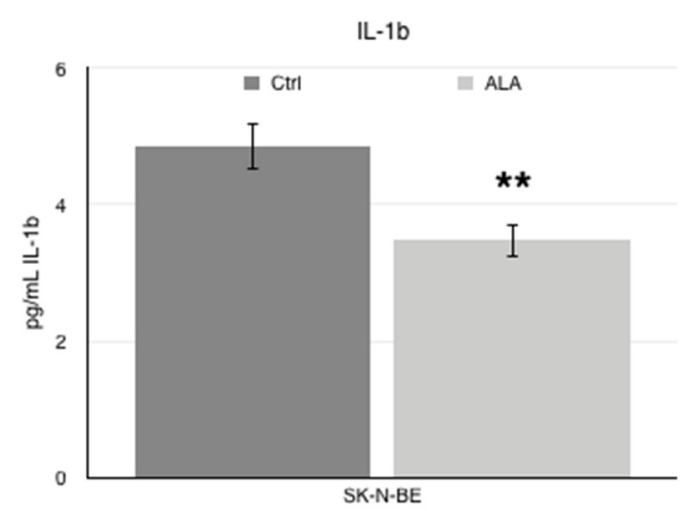

B

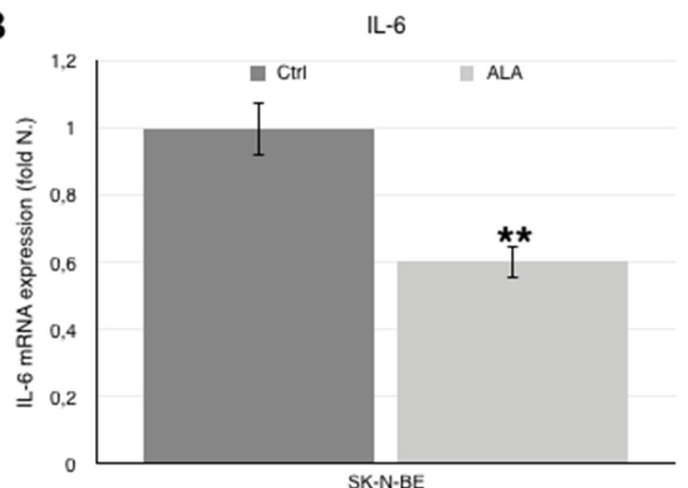

D

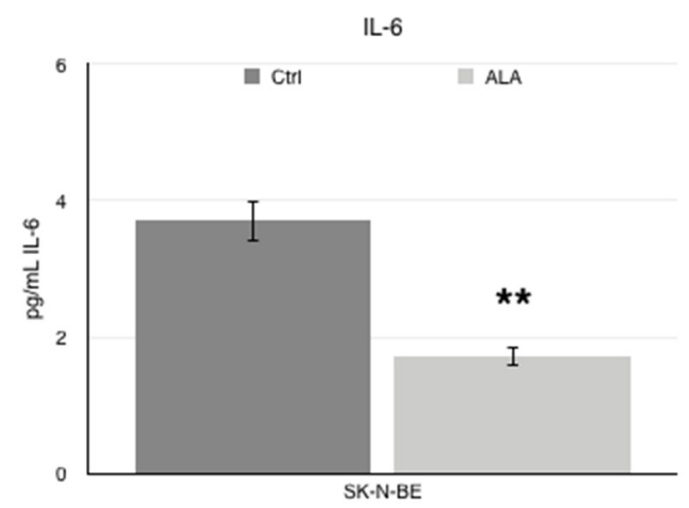

Figure 2. mRNA expression and protein levels of IL-1 $\beta$ and IL-6. IL-1 $\beta$ (A) and IL-6 (B) mRNA expression levels, as determined by real time-PCR, in SK-N-BE cells treated with control (dark grey columns) and ALA supplemented (light grey columns) medium. IL-1 $\beta$ (C) and IL-6 (D) protein levels in the culture medium, as determined by ELISA test, SK-N-BE cells treated with control (dark grey columns) and ALA supplemented (light grey columns) medium. Histograms indicate the mean value \pm SEM. ${ }^{* *} p<0.001$ vs. Ctrl.

\section{Discussion}

The data herein reported adds to an increasing amount of literature demonstrating that the expression of IL-1 $\beta$ and IL-6 is modulated by epigenetic mechanisms. Specifically, we showed that treating SK-N-BE cells with ALA induces hypermethylation of IL-1 $\beta$ and IL-6 5'-flanking regions, and that hypermethylation is associated with reduced mRNA expression and protein release in the culture medium. Taking advantage of a modified bisulphite assay [42], we also confirmed that in human neuroblastoma cells, the observed modulation of the DNA methylation patterns does not only affect the cytosines associated with the CpG dinucleotides. Discrete and dynamically changing non-CpG methylation was indeed observed in both promoter regions, as previously shown in different experimental models for the same genes [26,37,38] and for other genes [42,43].

Non-CpG methylation has been, so far, considered as restricted to embryonic tissues and stem cells [44-46]. More recently, growing evidence indicates that unexpectedly high levels of non-CpG methylation (25-35\% of total DNA methylation) are present in the adult brains of both mice and humans $[47,48]$. At present, we can affirm that non-CpG methylation plays a functional role also in adult mammalian tissues [49,50], including human brain [51].

The observation that IL-1 $\beta$ and IL-6, up-regulated in the inflammation response occurring during neurodegenerative processes, undergo epigenetic regulation through modulation of the DNA methylation pattern reinforces the idea that DNA methylation plays a central role in the pathological processes responsible for the onset of neurodegenerative diseases [52-55]. 
ALA was already indicated as a potential therapeutic agent in aging-associated neurodegenerative disorders [18-20], and it was successfully studied in neuroblastoma cell models, showing beneficial effects against oxidative stress, improving the antioxidant response of the cells [56-59]. Here, we disclosed a further biomolecular mechanism responsible for the anti-oxidant and anti-inflammatory effects of ALA. ALA concentration used in the present work $(0.5 \mathrm{mM})$ can be considered quite high, although a large range of doses can be found described in literature, ranging from few micromolar to even $4 \mathrm{mM}$; the concentration of the active $(R)-(+)$-enantiomer in our experiment is expected to be $0.25 \mathrm{mM}$. Preliminary (data not shown) experiments in different cell cultures showed that ALA concentration ranging from 0.1 to $4 \mathrm{mM}$ had no side effects on cell viability and growth.

The use of cancer cell lines represents a major limit, although it is also a necessary step in order to be able to perform ex vivo and in vivo studies. A second limitation of the present work is represented by the fact that no stress inducers were used to exacerbate inflammation in cell cultures, although cancer cells already show high inflammation levels with respect to normal cells. This seems particularly puzzling, since IL-1 $\beta$ secretion is known to be under regulation of different specific mechanisms triggered by inflammatory stimuli, including canonical and non-canonical pathways; whether the observed secretion in basal conditions is a consequence of the cancerous nature of the model used, remains to be ascertained. However, the aim of the present work was to disclose the existence of the epigenetic mechanisms associated to ALA supplementation. Further studies are obviously necessary to translate the observations and the mechanisms reported here, firstly in pre-clinical in vivo models of neurodegenerative diseases, and then in humans; nevertheless, this data strongly points out the potential of ALA as an elective antioxidant to be used to complement the therapies currently in use for the treatment of neurodegenerative diseases and in the preventive treatment of aging.

Supplementary Materials: The following are available online at www.mdpi.com/2076-3921/6/4/74/s1, Figure S1: mRNA expression levels, as determined by Real Time-PCR, in SK-N-BE cells treated with control (dark grey columns) and ALA supplemented (light grey columns) medium using GAPDH (A,B) and 18S (C,D) for normalization. Histograms indicate the mean value \pm s.e.m. ${ }^{* *} p<0.001$ vs. Ctrl.

Acknowledgments: This study was supported by grants from Sapienza University of Rome, Ateneo Federato 2014-2015. The authors are grateful to Myselis Santiago-Reyes for her skillful assistance.

Author Contributions: Andrea Fuso performed expression and methylation assays. Simona Dinicola and Sara Proietti contributed to the cell cultures experiments. The overall experimental design was conceived and supervised by Andrea Fuso and Mariano Bizzarri. The paper was written by Andrea Fuso and Mariano Bizzarri. Alessandra Cucina helped in preparing the manuscript for submission. All authors have read and approved the final manuscript.

Conflicts of Interest: Mariano Bizzarri and Andrea Fuso are scientific consultants for Lo.Li.Pharma.

\section{References}

1. Bilska, A.; Włodek, L. Lipoic acid-The drug of the future? Pharmacol. Rep. 2005, 57, 570-577. [PubMed]

2. Bast, A.; Haenen, G.R. Lipoic acid: A multifunctional antioxidant. Biofactors 2003, 17, 207-213. [CrossRef] [PubMed]

3. Biewenga, G.P.; Haenen, G.R.; Bast, A. The pharmacology of the antioxidant lipoic acid. Gen. Pharmacol. 1997, 29, 315-331. [CrossRef]

4. Packer, L.; Witt, E.H.; Tritschler, H.J. Alpha-Lipoic acid as a biological antioxidant. Free Radic. Biol. Med. 1995, 19, 227-250. [CrossRef]

5. Kim, Y.S.; Podder, B.; Song, H.Y. Cytoprotective effect of alpha-lipoic acid on paraquat-exposed human bronchial epithelial cells via activation of nuclear factor erythroid related factor-2 pathway. Biol. Pharm. Bull. 2013, 36, 802-811. [CrossRef] [PubMed]

6. Koriyama, Y.; Nakayama, Y.; Matsugo, S.; Kato, S. Protective effect of lipoic acid against oxidative stress is mediated by Keap1/Nrf2-dependent heme oxygenase-1 induction in the RGC-5 cell line. Brain Res. 2013, 1499, 145-157. [CrossRef] [PubMed] 
7. Ying, Z.; Kampfrath, T.; Sun, Q.; Parthasarathy, S.; Rajagopalan, S. Evidence that $\alpha$-lipoic acid inhibits NF- $\mathrm{kB}$ activation independent of its antioxidant function. Inflamm. Res. 2011, 60, 219-225. [CrossRef] [PubMed]

8. Kim, H.S.; Kim, H.J.; Park, K.G.; Kim, Y.N.; Kwon, T.K.; Park, J.Y.; Lee, K.U.; Kim, J.G.; Lee, I.K. Alpha-lipoic acid inhibits matrix metalloproteinase-9 expression by inhibiting NF-kB transcriptional activity. Exp. Mol. Med. 2007, 39, 106-113. [CrossRef] [PubMed]

9. Monastra, G.; De Grazia, S.; Cilaker Micili, S.; Goker, A.; Unfer, V. Immunomodulatory activities of alpha lipoic acid with a special focus on its efficacy in preventing miscarriage. Expert Opin. Drug Deliv. 2016, 13, 1695-1708. [CrossRef] [PubMed]

10. Packer, L. Alpha-Lipoic acid: A metabolic antioxidant which regulates NF-kappa B signal transduction and protects against oxidative injury. Drug Metab. Rev. 1998, 30, 245-275. [CrossRef] [PubMed]

11. Devi, Y.S.; DeVine, M.; DeKuiper, J.; Ferguson, S.; Fazleabas, A.T. Inhibition of IL-6 signaling pathway by curcumin in uterine decidual cells. PLoS ONE 2015, 10, e0125627. [CrossRef] [PubMed]

12. Sun, F.; Shi, J.; Chen, S.; Deng, C.; Hu, X.; Li, H.; Li, G.; Liu, Y.; Dong, N. Lazaroid U-74389G inhibits the osteoblastic differentiation of IL-1 $\beta$-indcued aortic valve interstitial cells through glucocorticoid receptor and inhibition of NF-kB pathway. J. Steroid Biochem. Mol. Biol. 2015, 152, 114-123. [CrossRef] [PubMed]

13. Xu, T.; Ni, M.M.; Huang, C.; Meng, X.M.; He, Y.H.; Zhang, L.; Li, J. NLRC5 Mediates IL-6 and IL-1 $\beta$ Secretion in LX-2 Cells and Modulated by the NF-kB/Smad3 Pathway. Inflammation 2015, 38, 1794-1804. [CrossRef] [PubMed]

14. Liu, X.; Ye, F.; Xiong, H.; Hu, D.N.; Limb, G.A.; Xie, T.; Peng, L.; Zhang, P.; Wei, Y.; Zhang, W.; et al. IL-1ß induces IL-6 production in retinal Müller cells predominantly through the activation of p38 MAPK/NF- $\mathrm{B}$ signaling pathway. Exp. Cell. Res. 2015, 33, 223-231. [CrossRef] [PubMed]

15. Tanabe, K.; Matsushima-Nishiwaki, R.; Kozawa, O.; Lida, H. Dexmedetomidine suppresses interleukin-1 $\beta$-induced interleukin-6 synthesis in rat glial cells. Int. J. Mol. Med. 2014, 34, 1032-1038. [CrossRef] [PubMed]

16. Li, G.; Fu, J.; Zhao, Y.; Ji, K.; Luan, T.; Zang, B. Alpha-lipoic acid exerts anti-inflammatory effects on lipopolysaccharide-stimulated rat mesangial cells via inhibition of nuclear factor kappa B (NF- $\mathrm{kB}$ ) signaling pathway. Inflammation 2015, 38, 510-519. [CrossRef] [PubMed]

17. Moura, F.A.; de Andrade, K.Q.; dos Santos, J.C.; Goulart, M.O. Lipoic Acid: Its antioxidant and anti-inflammatory role and clinical applications. Curr. Top. Med. Chem. 2015, 15, 458-483. [CrossRef] [PubMed]

18. Costantino, M.; Guaraldi, C.; Costantino, D.; De Grazia, S.; Unfer, V. Peripheral neuropathy in obstetrics: Efficacy and safety of $\alpha$-lipoic acid supplementation. Eur. Rev. Med. Pharmacol. Sci. 2014, 18, 2766-2771. [PubMed]

19. Di Geronimo, G.; Caccese, A.F.; Caruso, L.; Soldati, A.; Passaretti, U. Treatment of carpal tunnel syndrome with alpha-lipoic acid. Eur. Rev. Med. Pharmacol. Sci. 2009, 13, 133-139. [PubMed]

20. Arivazhagan, P.; Panneerselvam, S.R.; Panneerselvam, C. Effect of DL-alpha-lipoic acid on the status of lipid peroxidation and lipids in aged rats. J. Gerontol. A. Biol. Sci. Med. Sci. 2003, 58, B788-B791. [CrossRef] [PubMed]

21. World Alzheimer Report 2016. Available online: https://www.alz.co.uk/research/world-report-2016 (accessed on 26 July 2017).

22. Iqbal, K.; Grundke-Iqbal, I. Alzheimer neurofibrillary degeneration: Significance, etiopathogenesis, therapeutics and prevention. J. Cell. Mol. Med. 2008, 12, 38-55. [CrossRef] [PubMed]

23. Gillette Guyonnet, S.; Abellan Van Kan, G.; Andrieu, S.; Barberger Gateau, P.; Berr, C.; Bonnefoy, M.; Dartigues, J.F.; de Groot, L.; Ferry, M.; Galan, P.; et al. IANA task force on nutrition and cognitive decline with aging. J. Nutr. Health Aging 2007, 11, 132-152. [PubMed]

24. Akiyama, H.; Barger, S.; Barnum, S.; Bradt, B.; Bauer, J.; Cole, G.M.; Cooper, N.R.; Eikelenboom, P.; Emmerling, M.; Fiebich, B.L.; et al. Inflammation and Alzheimer's disease. Neurobiol. Aging 2000, 21, 383-421. [CrossRef]

25. McGeer, P.L.; McGeer, E.G. Inflammation and the degenerative diseases of aging. Ann. N. Y. Acad. Sci. 2004, 1035, 104-116. [CrossRef] [PubMed]

26. Lee, Y.J.; Han, S.B.; Nam, S.Y.; Oh, K.W.; Hong, J.T. Inflammation and Alzheimer's disease. Arch. Pharm. Res. 2010, 33, 1539-1556. [CrossRef] [PubMed] 
27. López-González, I.; Schlüter, A.; Aso, E.; Garcia-Esparcia, P.; Ansoleaga, B.; LLorens, F.; Carmona, M.; Moreno, J.; Fuso, A.; Portero-Otin, M.; et al. Neuroinflammatory signals in Alzheimer disease and APP/PS1 transgenic mice: Correlations with plaques, tangles, and oligomeric species. J. Neuropathol. Exp. Neurol. 2015, 74, 319-344. [CrossRef] [PubMed]

28. Rubio-Perez, J.M.; Morillas-Ruiz, J.M. A review: Inflammatory process in Alzheimer's disease, role of cytokines. Scientific World J. 2012. [CrossRef] [PubMed]

29. Dursun, E.; Gezen-Ak, D.; Hanağası, H.; Bilgiç, B.; Lohmann, E.; Ertan, S.; Atasoy, İ.L.; Alaylığlu, M.; Araz, Ö.S.; Önal, B.; et al. The interleukin 1 alpha, interleukin 1 beta, interleukin 6 and alpha-2-macroglobulin serum levels in patients with early or late onset Alzheimer's disease, mild cognitive impairment or Parkinson's disease. J. Neuroimmunol. 2015, 283, 50-57. [CrossRef] [PubMed]

30. Xie, L.; Lai, Y.; Lei, F.; Liu, S.; Liu, R.; Wang, T. Exploring the association between interleukin-1 $\beta$ and its interacting proteins in Alzheimer's disease. Mol. Med. Rep. 2015, 11, 3219-3228. [CrossRef] [PubMed]

31. Rothaug, M.; Becker-Pauly, C.; Rose-John, S. The role of interleukin-6 signaling in nervous tissue. Biochim. Biophys. Acta 2016, 1863, 1218-1227. [CrossRef] [PubMed]

32. Nicolia, V.; Cavallaro, R.A.; López-González, I.; Maccarrone, M.; Scarpa, S.; Ferrer, I.; Fuso, A. DNA Methylation Profiles of Selected Pro-Inflammatory Cytokines in Alzheimer Disease. J. Neuropathol. Exp. Neurol. 2017, 76, 27-31. [CrossRef] [PubMed]

33. Aoi, Y.; Nakahama, K.; Morita, I.; Safronova, O. The involvement of DNA and histone methylation in the repression of IL-1 $\beta$-induced MCP-1 production by hypoxia. Biochem. Biophys. Res. Commun. 2011, 414, 252-258. [CrossRef] [PubMed]

34. Tekpli, X.; Landvik, N.E.; Anmarkud, K.H.; Skaug, V.; Haugen, A.; Zienolddiny, S. DNA methylation at promoter regions of interleukin $1 \mathrm{~B}$, interleukin 6, and interleukin 8 in non-small cell lung cancer. Cancer Immunol. Immunother. 2013, 62, 337-345. [CrossRef] [PubMed]

35. Hashimoto, K.; Oreffo, R.O.; Gibson, M.B.; Goldring, M.B.; Roach, H.I. DNA demethylation at specific CpG sites in the IL1B promoter in response to inflammatory cytokines in human articular chondrocytes. Arthritis Rheum. 2009, 60, 3303-3313. [CrossRef] [PubMed]

36. Cho, S.H.; Chen, J.A.; Sayed, F.; Ward, M.E.; Gao, F.; Nguyen, T.A.; Krabbe, G.; Sohn, P.D.; Lo, I.; Minami, S.; et al. SIRT1 deficiency in microglia contributes to cognitive decline in aging and neurodegeneration via epigenetic regulation of IL-1ß. J. Neurosci. 2015, 35, 807-818. [CrossRef] [PubMed]

37. Fuso, A.; Iyer, A.M.; van Scheppingen, J.; Maccarrone, M.; Scholl, T.; Hainfellner, J.A.; Feucht, M.; Jansen, F.E.; Spliet, W.G.; Krsek, P.; et al. Promoter-specific hypomethylation correlates with IL-1 $\beta$ overexpression in Tuberous Sclerosis Complex (TSC). J. Mol. Neurosci. 2016, 59, 464-470. [CrossRef] [PubMed]

38. Dinicola, S.; Santiago-Reyes, M.; Canipari, R.; Cucina, A.; Bizzarri, M.; Fuso, A. Alpha-lipoic acid represses IL-1B and IL-6 through DNA methylation in ovarian cells. PharmaNutrition 2017, 5, 77-83. [CrossRef]

39. Fuso, A.; Nicolia, V.; Cavallaro, R.A.; Scarpa, S. DNA methylase and demethylase activities are modulated by one-carbon metabolism in Alzheimer's disease models. J. Nutr. Biochem. 2011, 22, 242-251. [CrossRef] [PubMed]

40. Fuso, A.; Cavallaro, R.A.; Zampelli, A.; D’Anselmi, F.; Piscopo, P.; Confaloni, A.; Scarpa, S. Gamma-Secretase is differentially modulated by alterations of homocysteine cycle in neuroblastoma and glioblastoma cells. J. Alzheimers Dis. 2007, 11, 275-290. [CrossRef] [PubMed]

41. Scarpa, S.; Fuso, A.; D'Anselmi, F.; Cavallaro, R.A. Presenilin 1 gene silencing by S-adenosylmethionine: A treatment for Alzheimer disease? FEBS Lett. 2003, 541, 145-148. [CrossRef]

42. Fuso, A.; Ferraguti, G.; Scarpa, S.; Ferrer, I.; Lucarelli, M. Disclosing bias in bisulfite assay: MethPrimers underestimate high DNA methylation. PLoS ONE 2015, 10, e0118318.

43. Fuso, A.; Ferraguti, G.; Grandoni, F.; Ruggeri, R.; Scarpa, S.; Strom, R.; Lucarelli, M. Early demethylation of non-CpG, $\mathrm{CpC}$-rich, elements in the myogenin $5^{\prime}$-flanking region: A priming effect on the spreading of active demethylation. Cell Cycle 2010, 9, 3965-3976. [CrossRef] [PubMed]

44. Guo, J.U.; Su, Y.; Shin, J.H.; Shin, J.; Li, H.; Xie, B.; Zhong, C.; Hu, S.; Le, T.; Fan, G.; et al. Distribution, recognition and regulation of non-CpG methylation in the adult mammalian brain. Nat. Neurosci. 2014, 17, 215-222. [CrossRef] [PubMed]

45. Xie, W.; Barr, C.L.; Kim, A.; Yue, F.; Lee, A.Y.; Eubanks, J.; Dempster, E.L.; Ren, B. Base-resolution analyses of sequence and parent-of-origin dependent DNA methylation in the mouse genome. Cell 2012, 148, 816-831. [CrossRef] [PubMed] 
46. Xie, W.; Schultz, M.D.; Lister, R.; Hou, Z.; Rajagopal, N.; Ray, P.; Whitaker, J.W.; Tian, S.; Hawkins, R.D.; Leung, D.; et al. Epigenomic analysis of multilineage differentiation of human embryonic stem cells. Cell 2013, 153, 1134-1148. [CrossRef] [PubMed]

47. Lister, R.; Mukamel, E.A.; Nery, J.R.; Urich, M.; Puddifoot, C.A.; Johnson, N.D.; Lucero, J.; Huang, Y.; Dwork, A.J.; Schultz, M.D.; et al. Global epigenomic reconfiguration during mammalian brain development. Science 2013, 341, 1237905. [CrossRef] [PubMed]

48. Guo, W.; Chung, W.Y.; Qian, M.; Pellegrini, M.; Zhang, M.Q. Characterizing the strand-specific distribution of non-CpG methylation in human pluripotent cells. Nucleic Acids Res. 2014, 42, 3009-3016. [CrossRef] [PubMed]

49. Patil, V.; Ward, R.L.; Hesson, L.B. The evidence for functional non-CpG methylation in mammalian cells. Epigenetics 2014, 9, 823-828. [CrossRef] [PubMed]

50. Pietrzak, M.; Rempala, G.A.; Nelson, P.T.; Hetman, M. Non-random distribution of methyl-CpG sites and non-CpG methylation in the human rDNA promoter identified by next generation bisulfite sequencing. Gene 2016, 585, 35-43. [CrossRef] [PubMed]

51. Jang, H.S.; Shin, W.J.; Lee, J.E.; Do, J.T. CpG and Non-CpG Methylation in Epigenetic Gene Regulation and Brain Function. Genes 2017, 8, 148. [CrossRef] [PubMed]

52. Fuso, A. The "golden age" of DNA methylation in neurodegenerative diseases. Clin. Chem. Lab. Med. 2013, 51, 523-534. [CrossRef] [PubMed]

53. Wen, K.X.; Miliç, J.; El-Khodor, B.; Dhana, K.; Nano, J.; Pulido, T.; Kraja, B.; Zaciragic, A.; Bramer, W.M.; Troup, J.; et al. The Role of DNA Methylation and Histone Modifications in Neurodegenerative Diseases: A Systematic Review. PLoS ONE 2016, 11, e0167201. [CrossRef] [PubMed]

54. Li, X.; Bao, X.; Wang, R. Neurogenesis-based epigenetic therapeutics for Alzheimer's disease (Review). Mol. Med. Rep. 2016, 14, 1043-1053. [CrossRef] [PubMed]

55. Cacabelos, R.; Torrellas, C. Epigenetics of Aging and Alzheimer's Disease: Implications for Pharmacogenomics and Drug Response. Int. J. Mol. Sci. 2015, 16, 30483-30543. [CrossRef] [PubMed]

56. Lardenoije, R.; Iatrou, A.; Kenis, G.; Kompotis, K.; Steinbusch, H.W.; Mastroeni, D.; Coleman, P.; Lemere, C.A.; Hof, P.R.; van den Hove, D.L.; et al. The epigenetics of aging and neurodegeneration. Prog. Neurobiol. 2015, 131, 21-64. [CrossRef] [PubMed]

57. Feuerecker, B.; Pirsig, S.; Seidl, C.; Aichler, M.; Feuchtinger, A.; Bruchelt, G.; Senekowitsch-Schmidtke, R. Lipoic acid inhibits cell proliferation of tumor cells in vitro and in vivo. Cancer Biol. Ther. 2012, 13, 1425-1435. [CrossRef] [PubMed]

58. Yamada, T.; Hashida, K.; Takarada-Iemata, M.; Matsugo, S.; Hori, O. $\alpha$-Lipoic acid (LA) enantiomers protect SH-SY5Y cells against glutathione depletion. Neurochem. Int. 2011, 59, 1003-1009. [CrossRef] [PubMed]

59. Jia, Z.; Hallur, S.; Zhu, H.; Li, Y.; Misra, H.P. Potent upregulation of glutathione and NAD(P)H: Quinone oxidoreductase 1 by alpha-lipoic acid in human neuroblastoma SH-SY5Y cells: protection against neurotoxicant-elicited cytotoxicity. Neurochem. Res. 2008, 33, 790-800. [CrossRef] [PubMed] 